\title{
Ultrastructure of Proechinophthirus zumpti (Anoplura, Echinophthiriidae) by Scanning Electron Microscopy
}

\section{Dolores del Carmen Castro/ ${ }^{+}$, Mariano Damian Romero*, Marcos Dreon}

\author{
Facultad de Ciencias Naturales y Museo La Plata, Paseo del Bosque, s/n, 1900, La Plata, Buenos Aires, Argentina \\ *Museo Municipal de Ciencias Naturales, Lorenzo Scaglia, Mar del Plata, Buenos Aires, Argentina
}

The ultrastructure of Proechinophthirus zumpti Werneck, 1955, mainly the external chorionic features of the egg, is described through electronic microscopy techniques. This species was first cited in Argentina, infesting Arctocephalus australis (Zimmermann, 1873). The morphological adaptations of adults and nymphs are described in both species of Proechinophthirus parasitic on Otariidae: P. fluctus (Ferris, 1916) and P. zumpti.

Key words: Proechinophthirus - Anoplura - ultrastructure - Echinopthtiriidae - Otariidae

Anoplura (Phthiraptera) parasitic on Otariidae (Carnivora) are so far represented by two genus of the Family Echinophthiriidae: Antarctophthirus Enderlein, 1906 and Proechinophthirus Ewing, 1923. The first one includes two species: A. callorhini (Osborn, 1899) found at the north of the Pacific Ocean and Bering Sea, and A. microchir (Trovessart \& Neumann, 1888) of Antartic distribution. The second is represented by two species: P. fluctus with the same distribution as A. callorhini, and P. zumpti whose distribution is restricted to Southern Africa (Durden \& Musser 1994). In this paper, P. zumpti is cited for the first time in Argentina enlarging its distribution, and Arctocephalus australis is mentioned for the first time as its host. The ultrastructure of the egg of this species is described, as well as the morphological ultrastructural adaptations of adults and nymphs. Both species of the genus Proechinophthirus parasitic on Otariidae are compared.

\section{MATERIALS AND METHODS}

The eggs, adults and nymphs of $P$. zumpti, were obtained from a juvenile two hair wolf, A. australis from Claromecó Beach, Tres Arroyos County, Buenos Aires Province, Argentina. The eggs were extracted and fixed in glutaraldehyde $3 \%$ and processed under scanning electronic microscope (SEM), following the techniques used by Castro et al. (1991). The adults and nymphs were separated after dehydration in acetone $\left(30^{\circ}, 50^{\circ}, 70^{\circ}, 90^{\circ}\right.$ and $\left.100^{\circ}\right)$. The samples were taken to the crucial point and mounted on metallic stubs, then they were coated with gold-palladium in a jeol vacuum metallizer. They were observed and photographed in the SEM service of La Plata Museum (MLP). The voucher specimens (no. 2935) were deposited in the collections of MLP, Buenos Aires, Argentina.

\footnotetext{
${ }^{+}$Corresponding author. Fax: +54-221-4257.527. E-mail: castrodreon@Impsat1.com.ar. and castrodreon@Lpsat.com Received 7 November 2001 Accepted 3 May 2002
}

Measurements of ultrastructural characteristics were done using the digital scale generated by the SEM service, and are expressed in micrometers.

\section{RESULTS}

Proechinophthirus zumpti Werneck, 1955

(Figs 1-19)

Diagnosis: species morphologically close to $P$. fluctus. It differs in form, size and cephalic and abdominal chaetotaxy of nymphs and adults, length of paramera, chaetotaxy of female genitalia and number of abdominal tergal and sternal setae.

By use of electron microscopy, some structures are now described or redescribed.

Male: head twice longer than wide, anterior border rounded, postantennal borders with 2 prominent conical processes, robust 4 segmented antennae, bearing the first one a typically spine-shaped setae similar dorsally and ventrally (Figs 1-2), third segment with a terminal caeloconic sensoria tactile; last antennal segment with a group of 10 apical chemoreceptors and 2 placodeas olfactory chemoreceptor of lateral-ventral position, forming an aster of 11-15 setae, implanted in the middle of a wide cavity (Fig. 3). Dorsal cephalic setae: 2 pairs of long and thin central setae in addition to 2 very small lateral ones; 2 pairs of preantennals setae of similar characteristics in addition to a very small anterior pair; 2 pairs of postantennals setae different in size; one pair of robust spine-shaped setae in postantennal central position, in addition to a thin and long lateral pair, one pair of long and thin setae on the basal postantennal process, and a conspicuous pair in the same apical process; one central posterior pair; 3 posterior pairs and 2 very long marginal setae (Fig. 4). Ventral cephalic setae: an array of 7 central thin setae in addition to 4 lateral setae of similar characteristics; one pair of spine-shaped postantennals setae and one long marginal posterior pair (Fig. 2). Thorax as wide as the head, bearing numerous setae different in size. Dorsal thoracic setae: 3 anterior arrays of 12-13 thin setae of equal size, in addition to one lateral robust pair, 4 posterior long and thin setae in addition to 2 robust lateral ones, and one thin and long central pair (Fig. 4). Ventral setae: numerous thin setae of the same size (Fig. 1). With- 
out sternal plate, dorsal central thoracic spiracle with wide atrium (Figs 4-5). First pair of legs very small, the other 2 larger and subequal, with strong adaptations of tibia-tarsus (Figs 6-9).

Abdomen elongated, scaly, strongly sculpted abdominal tegument and dorsal and ventrally uniform, ventral scaling uniform and pavement like (Fig. 10), dorsalscaling lanceolate (Fig. 11) covered with 3 groups of setae, a medial one and 2 marginal; 6 pairs of dorsal spiracles, hardly perceptible with conventional optic microscopy, protected by the tegument, bell-shaped with a wide atrium (Figs 1112).

Robust genital apparatus, with short and wide basal plate, wide lightly curved parameres, pseudopenis widely developed.

Measurements: total body length: $1.84 \mathrm{~mm}(\mathrm{n}=3)$ (range =1.84-2.01).

Female: general characteristics similar to those of male, differing in measures and genitalia, which is totally surrounded by setae of different sizes. Measurements: total
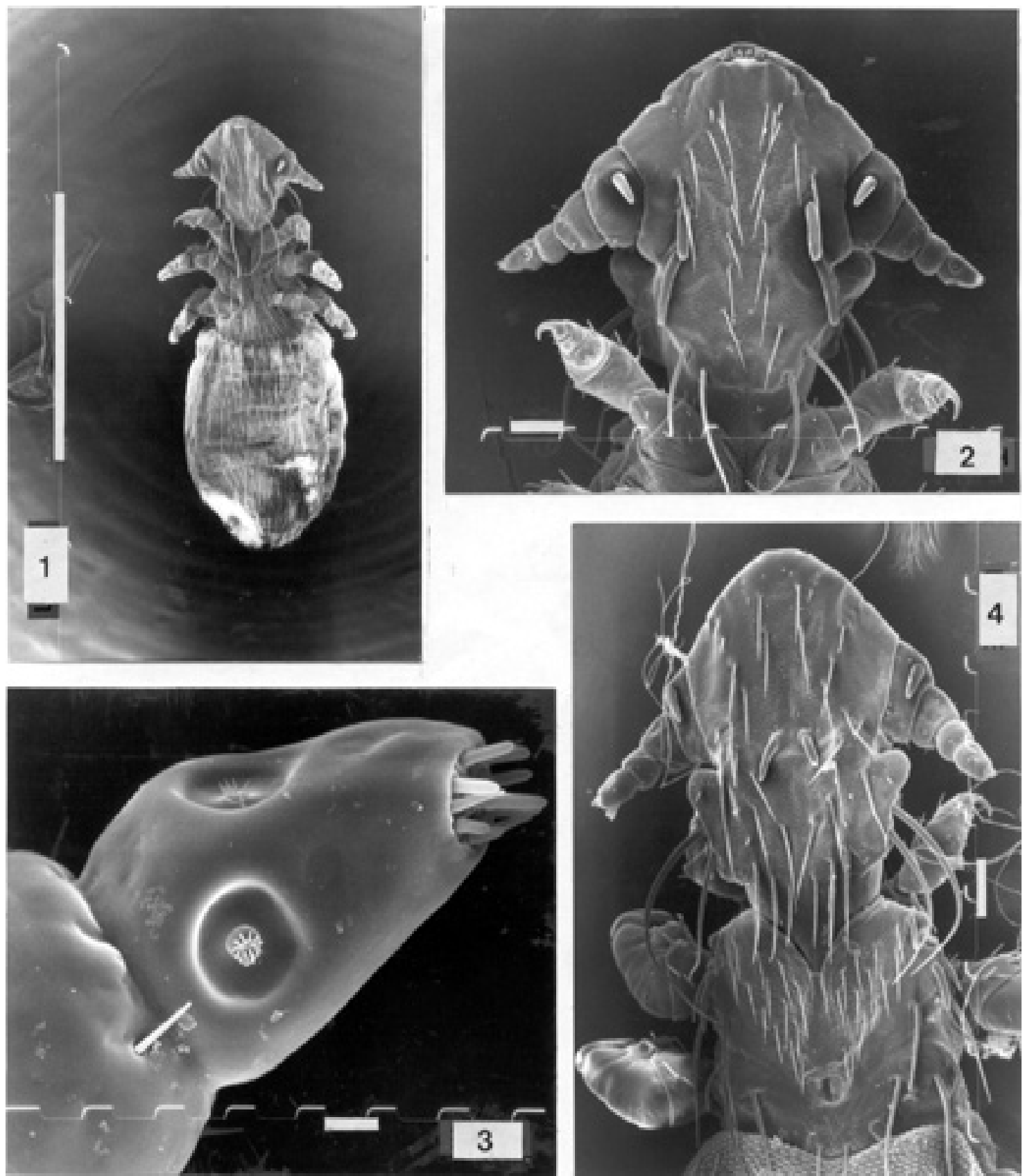

Proechinophthirus zumpti Werneck, 1955. Electronic microphotograph. Fig. 1: male ventral view, 50x, bar 1000 $\mu \mathrm{m}$. Fig. 2: head in ventral view, 150x, bar $100 \mu \mathrm{m}$. Fig. 3: third and fourth segment antennal, 1500x, bar $10 \mu \mathrm{m}$. Fig. 4: head and torax of the male in dorsal view, 150x, bar $100 \mu \mathrm{m}$. 
body length: $2.39 \mathrm{~mm}(\mathrm{n}=5)($ range $=2.20-2.47)$.

Nymphal phases - Nimph I: total body length: $0.90 \mathrm{~mm}$. Similar to nimph II and III, differing in size and chaetotaxy. Nimph II: total body lengh: $1.35(\mathrm{n}=2)$. Similar to III, differing in the smaller number of cephalic, thoracic and abdominal setae, reflecting the tendency to grouping that remains constant in all the developmental stages. Nimph III: total body length: $1.90 \mathrm{~mm}(\mathrm{n}=3)$, chaetotaxy characteristics are kept in the adult, differing in the presence of 7 robust apical setae and in the smaller amount and distri- bution of thoracic setae (Figs 13-14).

Egg: cemented to the hair with scarce spumaline; can be completely observed; are placed individually or in clusters (Figs 15-16). Operculum: slightly conical with irregular relief, and agglutinations that form a thick and rather short fanero (Figs 17-18), 12-15 air chambers hardly perceptible, little elevated with central, wide hole (Figs 1819), eccentric micropyla. Amphora: even in all its extension, ellipsoidal, with strong impression of the opercular callus (Figs 16-17).
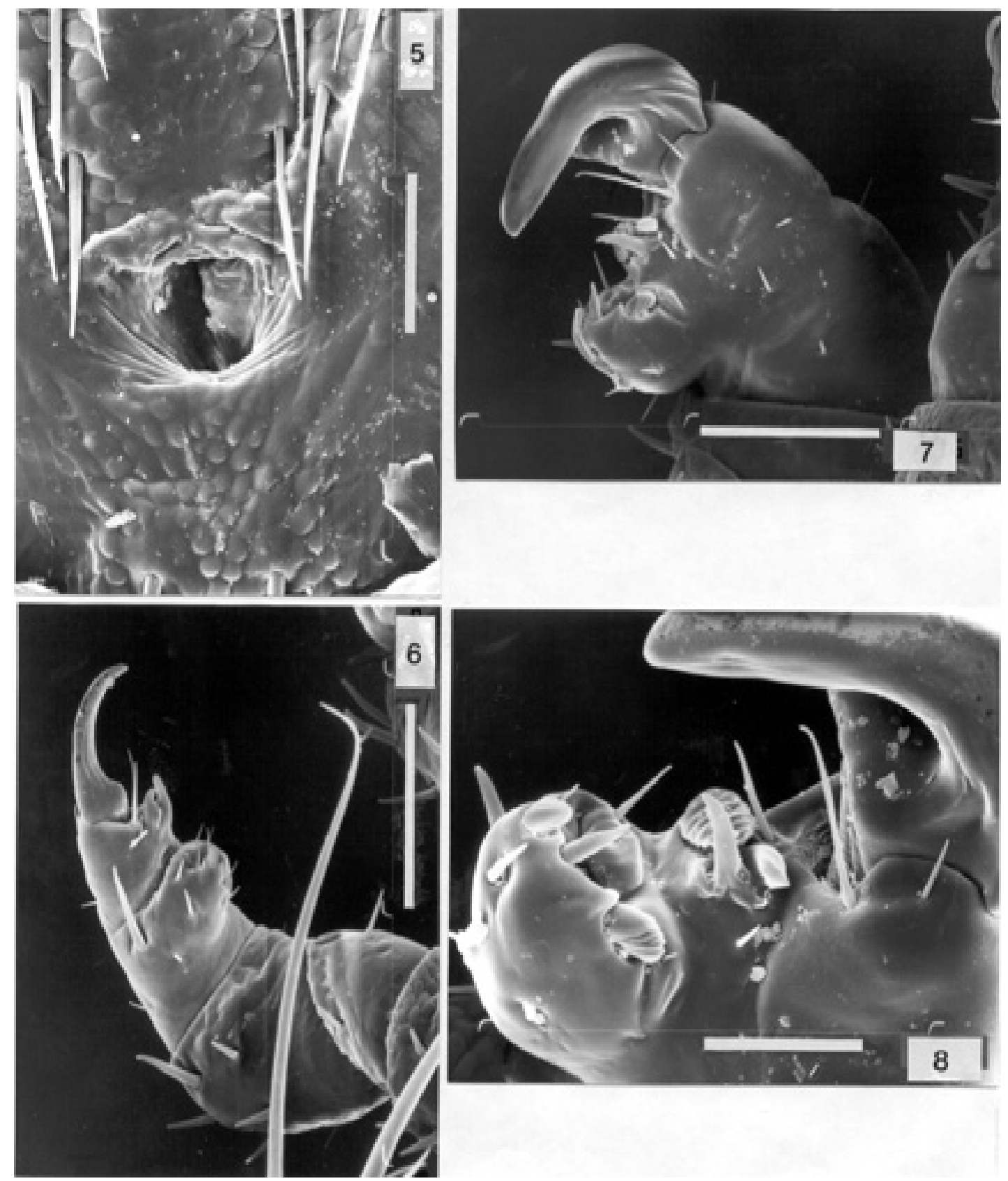

Proechinophthirus zumpti Werneck, 1955. Electronic microphotograph. Fig. 5: thoracic spiracle, 150x, bar $50 \mu \mathrm{m}$. Fig. 6: first pair of leg of the male, 500x, bar $100 \mu \mathrm{m}$. Fig. 7: second pair of leg of the male, 500x, bar $100 \mu \mathrm{m}$. Fig. 8: second pair of leg, modification at level of tibia-tarsus, 1000x, bar $50 \mu \mathrm{m}$. 
Type host: Arctocephalus australis Claromecó, Tres Arroyos, Buenos Aires Province, Argentina (Museum Lorenzo Scaglia coll.).

Specimens examined: 3 males; 5 females; 1 nymph I; 2 nymph II and 3 nymph III, host as above, 11/11/1999 MD Romero coll.

Host: the family Otariidae is represented in Argentina by two genera: Arctocephalus Geofroy \& Cuvier, 1826 and Otaria Péron, 1816. The first one has three species: $A$. australis; A. gazella (Peters, 1875) and A. tropicalis (Gray, 1872 ), and the second one is monotypic, O.flavescens (Shaw, 1800) according to Galliari et al. (1996).

A. australis is one of the three species that inhabits the continental territory of Argentina, being the less numerous species of Otariidae in this country. It is smaller than the otarias or one-hair wolves that inhabit the port of Mar del Plata and Península Valdez. A. australis is distributed along the South American costs of the Atlantic and Pacific oceans, from the State of São Paulo, Brazil, up to Paracas peninsula in Southern Lima, Perú (Repenning et al. 1971, King 1983). It has settlements in the six main islands of Uruguay, in the Southeastern Atlantic (VazFerreira 1987), and numerous concentrations along the coasts of Argentina in Chubut, Santa Cruz and Tierra del Fuego provinces and adjacent islands. The largest group in Argentina is placed on Isla Rasa, Chubut province. Thirty settlements have been reported for Argentina in Malvinas Islands; Isla de los Estados; Tierra del Fuego; Santa Cruz and Buenos Aires (Carrara 1952, Laws 1953, Godoy 1963, Schiavini 1987).

\section{DISCUSSION}

Proechinophthirus is an exclusive parasite of Otariidae and only two species were so far known: P. fluctus on Callorhinus ursinus and Eumetopius jubatus and P. zumpti on A. pusillus and A. australis, here mentioned. Up to date, no Anoplura of this family of Carnivora were known in Argentina. New parasitological revisions of the four
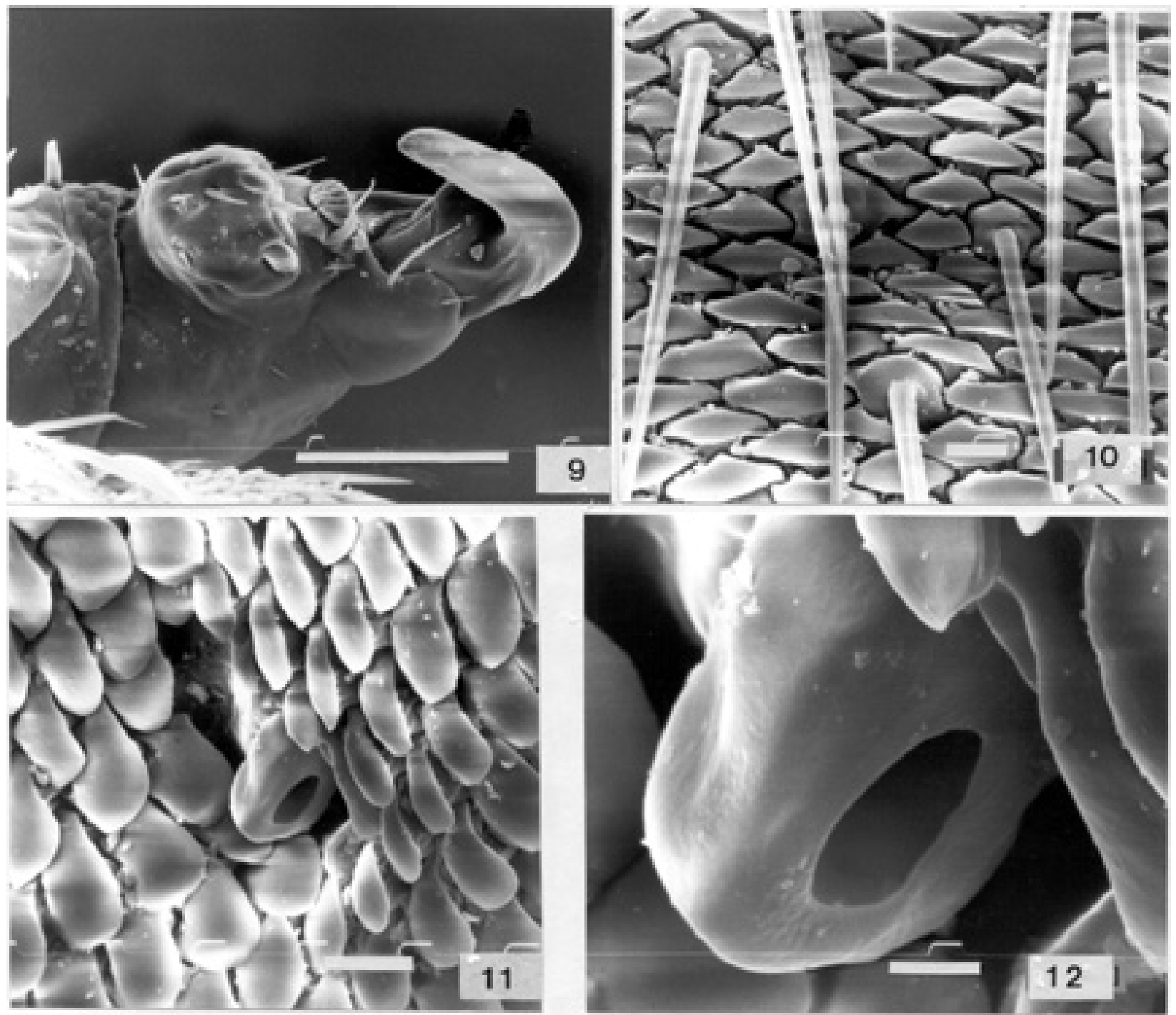

Proechinophthirus zumpti Werneck, 1955. Electronic microphotograph. Fig. 9: third pair of leg, 500x, bar 100 $\mu$ m. Fig. 10: abdominal cuticle in ventral view, 1500x, bar $10 \mu \mathrm{m}$. Fig. 11: abdominal cuticle in dorsal view and spiracle, 750x, bar 10 $\mu \mathrm{m}$. Fig. 12: abdominal spiracle, 2000x, bar $10 \mu \mathrm{m}$. 

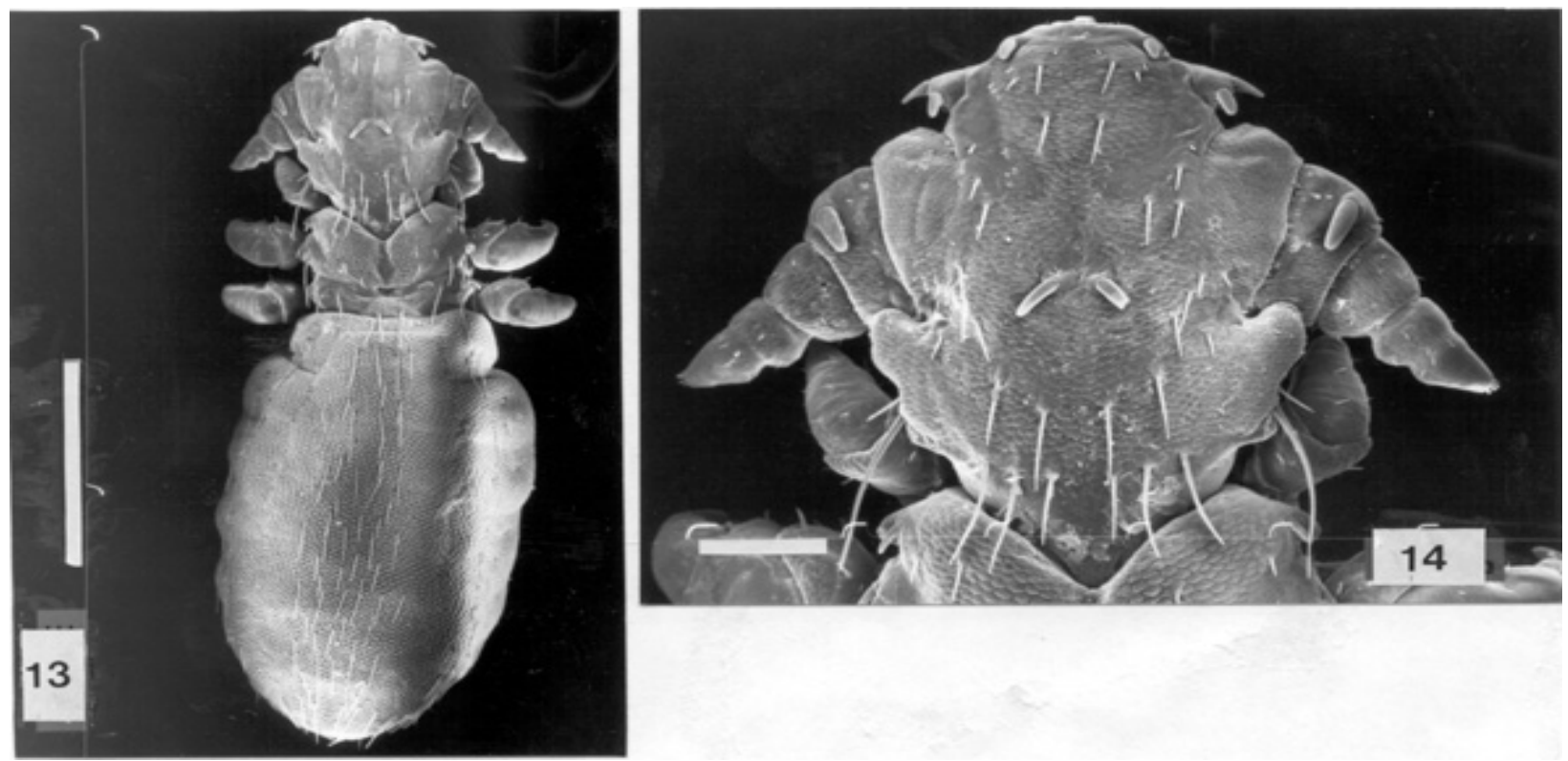

Proechinophthirus zumpti Werneck, 1955. Electronic microphotograph. Fig. 13: nymph III in dorsal view, 75x, bar $500 \mu \mathrm{m}$. Fig. 14: head nymph III in doral view, 200x, bar $100 \mu \mathrm{m}$.
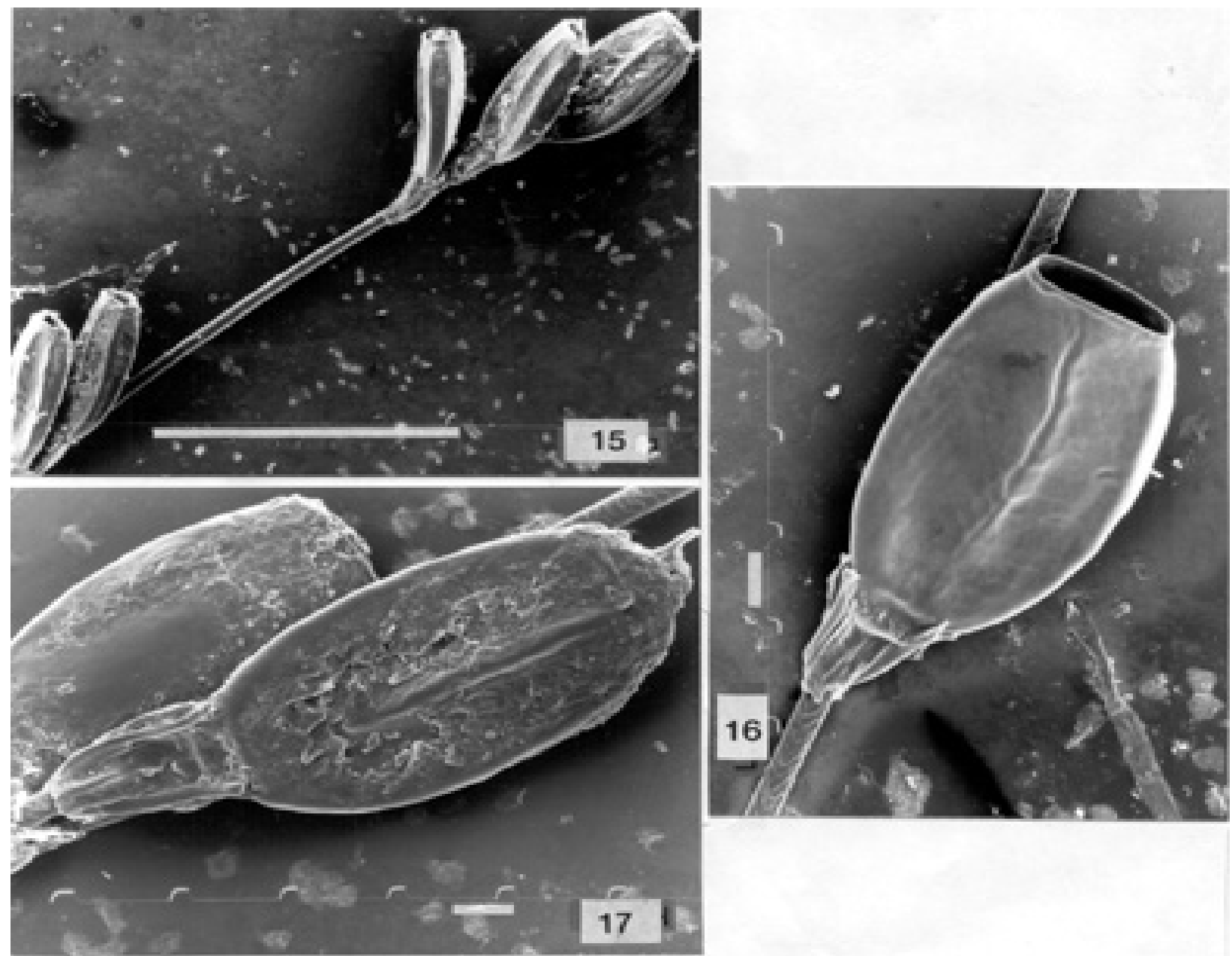

Proechinophthirus zumpti Werneck, 1955. Electronic microphotograph. Fig. 15: eggs, setting clusters, 75x, bar 1000 $\mu$ m. Figs 16-17: egg, general view, 200x, bar $100 \mu \mathrm{m}$. 


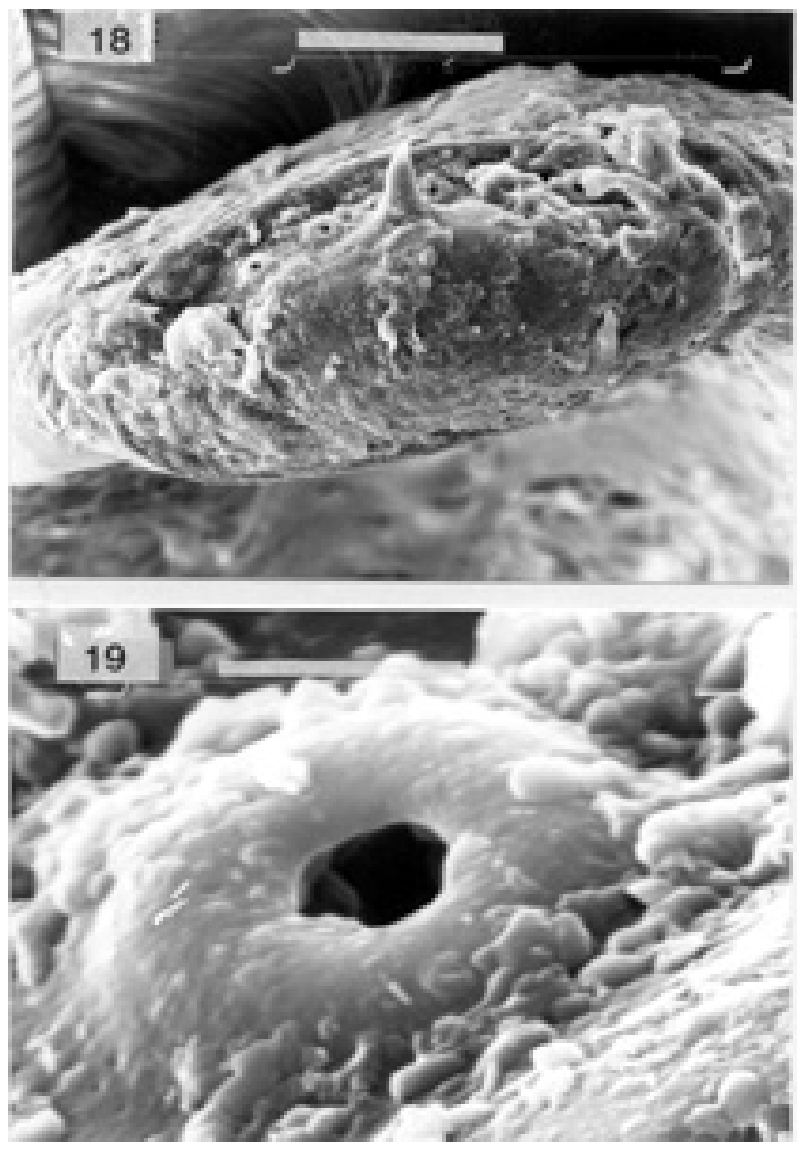

Proechinophthirus zumpti Werneck, 1955. Electronic microphotograph. Fig. 18: operculum showing air chambers, 750x, bar 50 $\mu \mathrm{m}$. Fig. 19: air chambers, 10000x, bar $5 \mu \mathrm{m}$

Otariidae species recorded in this country will probably enlarge the list of parasites, as well as improve the knowledge of their geographical distribution, and their phylogenetic relationships.

P. zumpti can be clearly distinguished from its related P. fluctus, as it was expressed by Werneck (1955) and Kim (1979). P. zumpti has highly specialized morphological adaptations related to the morphological and physiological characteristics of its host. These are reflected mainly in the second and third pairs of legs, which have the tibiatarsi strongly adapted to apprehension, to counteract the slipping on wet and highly lubricated hair characteristic of these otarids. The abdominal scaling is an adaptation to the movement of these insects, which also protects the breathing openings, of particular structure. In addition, the eggs of $P$. zumpti show reproductive strategies, as the air chambers scarcely elevated with wide opening and eccentric micropyla. The fact that the adults of this species, unlike $P$. fluctus, maintain nymph characteristics, particularly those referred to the cephalic and abdominal chaetotaxy, may be as expressed by Kim (1979), explained in evolutionary terms. In this sense, the characteristics of nymph-adult of these two species may support the monophyletic character of Proechinophthirus and consequently the observed relationship of these parasites with the Otariidae (one-hair seals and two-hair seals).

\section{REFERENCES}

Carrara IS 1952. Lobos Marinos, Pingüinos y Guaneras de las Costas del Litoral Marítimo e Islas Adyacentes de la Republica Argentina, Publicación especial, Catedra de Higiene e Industrias, Facultad de Ciencias Veterinarias, Universidad Nacional de La Plata, 171 pp.

Castro DC, Cicchino AC, De Villalobos LC 1991. A comparative study of the external architecture of the eggs of some neotropical species of the genus Hoplopleura Enderlein, 1904 (Phthiraptera, Anoplura). Revta Bras Ent 35: 663669.

Durden LA, Musser GG 1994. The sucking lice (Insecta, Anoplura) of the world: a taxonomic checklist with records of mammalian hosts and geographical distribution. Bull Amer Mus Natl Hist 218: 1-90.

Galliari CA, Pardiñas UFJ, Goin FJ 1996. Lista comentada de los mamíferos argentinos. Mast Neot 3: 39-61.

Godoy JC 1963. Caza de Pinnipedos. Consejo Federal de Inversiones. Serie Evaluación de los Recursos Naturales de la Republica Argentina (1era etapa), p. 133-152.

Kim KC 1979. Life stages and population of Proechinopthtirus zumpti (Anoplura: Echinophthiriidae), from the cape fur seal (Arctocephallus pusillus). J Med Entomol 16: 497-501.

King JE 1983. Seals of the World, Brithish Museum, Natural History and Cornell University Press, England, 240 pp.

Laws RM 1953. The seal of the Falkland Island and dependencies. Oryx 2: 87-97.

Repenning CA, Peterson RS, Hubbs CL 1971. Contributions to the systematics of the southern fur seals, with particular reference to the Juan Fernández and Guadalupe species. Antartic Res Series 18: 1-34.

Schiavini ACM 1987. Una aproximación a la predación de los aborígenes prehistóricos del canal de Beagle sobre los Pinnipedos. Anais Segunda Reunião de Trabalho de Especialistas em Mamíferos Aquáticos do Sul, Rio de Janeiro, 1986, p. 81-82.

Vaz-Ferreira RA 1987. South American fur seal, Arctocephalus australis, in Uruguay. In JP Croxall, RL Gentry (eds), Status, Biology and Ecology of Fur Seals, NOAA Technical Report, NMFS 51, p. 29-32.

Werneck FL 1955. Novo anopluro de leão marinho. Rev Brasil Biol 15: 419-421. 